\title{
PERAN KARANG TARUNA DALAM PENUMBUHKEMBANGAN MORAL GENERASI MUDA (Studi di Desa Maria Kecamatan Wawo Kabupaten Bima)
}

\author{
Ardiansyah $^{1}$, Yuliatin ${ }^{2}$, Muh Zubair ${ }^{3}$ \\ Jurusan Pendidikan IPS Fakultas Keguruan dan Ilmu Pendidikan Universitas Mataram \\ ardiansyahhadi26@gmail.com
}

\begin{abstract}
ABSTRAK
Penelitian ini bertujuan untuk mengetahui : (1) Peran karang taruna dalam penumbuhkembangan moral generasi muda di Desa Maria Kecamatan Wawo Kabupaten Bima. (2) Apa saja faktor yang mendukung karang taruna untuk menumbuhkembangkan moral generasi muda di Desa Maria Kecamatan Wawo Kabupaten Bima. Penelitian ini menggunakan pendekatan kualitatif dengan jenis fenomenologi. Subjek penelitian ini adalah karang taruna pelopor dan generasi muda di Desa Maria dengan informan pengurus karang taruna pelopor Desa Maria, kepala Daesa Maria Kecamatan Wawo Kabupaten Bima. Teknik pengumpulan data yaitu tehnik observasi, wawancara dan dokumentasi. Kemudian data yang sudah terkumpul dianalisis dengan deskripsi melalui langkah reduksi data, penyajian data dan menarik kesimpulan. Hasil penelitian ini menunjukkan bahwa peran karang taruna dalam penumbuhkembangan moral generasi muda di Desa Maria Kecamatan wawo kabupaten bima, penumbuhkembangan moral generasi muda dengan melalui beberapa program kerja dari karang taruna. Permaslahan-permasalahan yang dihadapi oleh karang taruna yaitu Sarana dan prasarana, dukungan dari pihak kelurahan dan masyarakat, Faktor penghambat, Masalah anggaran, Kurang aktifnya generasi muda karang taruna dalam mengikuti kegiatan, Kurang tenaga Pembina. Upaya untuk mengatasi permasalahan seperti : 1) sarana dan prasarana, 2) mengadakan rapat dengan pengurus karang taruna dan pemuda, 3) mengadakan dialog dengan pemerintah desa.
\end{abstract}

Kata Kunci :Karang Taruna, Penumbuhkembangan Moral, Generasi Muda

\begin{abstract}
This study aims to determine: (1) The role of youth organizations in the moral development of the younger generation in Maria Village, Wawo District, Bima Regency. (2) What are the factors that support youth organizations to develop the morale of the young generation in Maria Village, Wawo District, Bima Regency. This study uses a qualitative approach to the type of phenomenology. The subjects of this research are the pioneer youth organizations and the younger generation in Maria Village with the informant of the Maria Village pioneer youth organization, the head of Maria Village, Wawo District, Bima Regency. Data collection techniques are observation, interview and documentation techniques. Then the data that has been collected is analyzed by description through data reduction steps, data presentation and drawing conclusions. The results of this study indicate that the role of youth organizations in the moral development of the young generation in Maria Village, Wawo District, Bima Regency, the moral development of the younger generation through several work programs from youth organizations. The problems faced by youth organizations are facilities and infrastructure, support from the village and community parties, inhibiting factors, budget problems, lack of active youth generation in participating in activities, lack of coaches. Efforts to overcome problems such as: 1) facilities and infrastructure, 2) holding meetings with youth and youth organizations, 3) holding a dialogue with the village government.
\end{abstract}

Keywords: Karang Taruna, Moral Development, Young Generation 


\section{PENDAHULUAN}

Generasi muda adalah generasi penerus bangsa dan pemudalah yang menjadi pemegang tongkat estafet perjuangan dan pembangunan bangsa Indonesia kedepanya guna bersaing secara global. Pemuda juga perlu memperhatikan bahwa mereka mempunyai fungsi sebagai agen perubahan dan sosial kontrol sehingga fungsi tersebut dapat berguna bagi masyarakat.

Kondisi pemuda saaat ini mengalami degradasi moral, terlena dengan kesenangan dan lupa akan tanggung jawab sebagai seorang pemuda (Herni, 2018:5). Pada tataran moral, sosial dan akademik, pemuda tidak lagi memberi contoh dan keteladanan baik kepada masyarakat. Sebagai kaum terpelajar, pemuda lebih banyak berorientasi pada hedonisme (berhura-hura), tidak banyak pemuda yang peka terhadap kondisi sosial masyarakat saat ini (Herni, 2018:7). Tampak jelas pada mereka yang sedang berada pada usia muda, terutama pada mereka yang hidup di kota-kota besar seluruh Indonesia sudah mengalami kemerosotan moral (Dradjat, 1970:156).

Moral adalah bidang kehidupan manusia dilihat dari segi kebaikannya sebagai manusia. Moral seseorang dapat dikatakan merosot atau tidak, perlu adanya patokan dan ketentuan minimal yang harus dipakai. Berkurangnya kesadaran moral generasi muda dapat menimbulkan berbagai permasalahan sosial seperti meningkatnya tindak kriminal, maraknya penyalahgunaan narkotika, hingga meningkatnya kenalakalan pada pemuda. Sehingga perlu dilakukan upaya-upaya konkret untuk menanggulanginya secara serius, dan salah satunya dengan cara penumbuhkembangan moral bagi generasi pemuda. Kesadaran moral memang tidak tumbuh begitu saja dalam diri seseorang, oleh sebab itu kesadaran moral harus ditumbuhkembangkan. Upaya untuk menumbuhkembangkan kesadaran moral generasi muda tersebut dapat dilakukan baik melalui pendidikan formal disekolah maupun melalui pendidikan informal di keluarga dan di masyarakat.

Pemuda sebagai generasi penerus, diharapkan dapat memerankan peranan kunci dalam pembangunan bangsa. Pemuda merupakan elemen penting dalam perubahan yang terjadi pada masyarakat. Pemuda diharapkan mampu membawa pola pikir dan cara hidup positif dalam kehidupan bermasyarakat dan pemuda memiliki peran yang signifikan dalam hal ini. oleh karena itu perlu adanya pihak yang memberikan mereka masukan, mendidik mereka tentang pola pikir dan cara hidup yang lebih baik, dan terus mensosialisasikan pola pikir dan cara hidup yang lebih. Agar para pemuda tidak terjerumus kedalam permasalahan yang menyimpang, maka perlu adanya sebuah organisasi yang mampu membuat generasi muda untuk ikut serta didalamnya seperti suatu organisasi karang taruna diberdayakan untuk mengembangkan generasi muda agar menjadi lebih baik dalam meneruskan pembangunan.

Organisasi karang taruna merupakan kumpulan individu dalam suatu wadah untuk menyalurkan aspirasi dan mengembangkan kesadaran moral kepada para generasi pemuda. Mereka diharapkan mampu dalam memberikan sumbangan ide - ide kreatif dalam segala segi bidang yang ada dalam lingkungannya. Menurut Mulyawan, (2009) karang taruna adalah (baik siswa maupun mahasiswa) untuk berorganisasi sejak dini. Karang taruna didirikan dengan tujuan untuk memberikan pembinaan dan pemberdayaan kepada generasi 
muda, misalnya dalam bidang keorganisasian, ekonomi, sosial, keagamaan, moral dan kesenian untuk mempraktekan dan menumbuhkembangkan moralitas generasi muda.

Berdasarkan hasil observasi yang dilakukan oleh peneliti di Desa Maria Kecamatan. Wawo Kabupaten Bima bahwa karang taruna sudah ada didesa tersebut, hasil wawancara dengan ketua karang taruna Desa Maria, bahwa karang taruna di Desa ini perlu dibentuk dan di kembangkan di masyarakat, sebab karang taruna merupakan wadah generasi muda untuk pengembangan karakter tanggung jawab dan kepedulian sosial pada diri generasi muda. Selain itu karang taruna juga merupakan wadah bagi pemuda untuk menyalurkan berbagai potensi dalam dirinya, karena dalam karang taruna terdapat berbagai macam kegiatan yang dapat mengembangkan karakter tanggung jawab dan kepeduliaan sosial pada diri seorang pemuda (Ramlin, 2020). Melalui kegiatan organisasi ini juga diharapkan mampu merubah keadaan moral generasi muda yang ada di Desa Maria Kecamatan Wawo Kabupaten Bima yang sangat memprihatinkan.

Berdasarkan dari hasil wawancara yang dilakukan dengan salah satu tokoh agama Desa Maria, yang sangat memprihatinkan adalah kondisi generasi muda di Desa Maria Kecamatan Wawo Kabupaten Bima banyak sekali generasi muda yang melanggar norma sosial, contohnya mereka minum-minuman berakohol, perkelahian, sex bebas dan banyak mereka yang menggunakan narkoba (Imran, 2020). Dalam kondisi yang demikian penumbuhkembangan moral terhadap generasi muda mempunyai peranan-peranan yang penting untuk membimbing dan menuntunnya sesuai dengan moral yang berlaku dimasyarakat. Melihat kondisi generasi muda yang berada di Desa Maria Kecamatan Wawo Kabupaten Bima sangat menghawatirkan. Dulu mereka sangat menjujung tinggi kearifan budaya dan mengedepankan kesopanan kini akibat pergaulan dan kemajuan tekhnologi malah membuat dampak yang buruk.

Keberadaan karang taruna di Desa Maria sangat penting untuk menumbuhkembangkan moral generasi muda, karena dilihat dari hasil wawancara ketua karang taruna Desa Maria, tokoh masyarakat dan tokoh agama bahwa keberadaan karang taruna ini sangat diperlukan, oleh sebab itu peneliti tertarik untuk melakukan penelitian tentang peran karang taruna pelopor Desa Maria Kecamatan Wawo Kabupaten Bima.

\section{METODE PENELITIAN}

Penelitian ini menggunakan pendekatan kualitatif dengan jenis fenomenologi. Pendekatan penelitian kualitatif adalah pendekatan penelitian yang digunakan untuk meneliti pada objek yang alamiah yakni objek yang berkembang apa adanya, tidak dimanipulasi oleh peneliti dan kehadiran peneliti tidak mempengaruhi dinamika pada obyek tersebut (Sugiyono, 2018:132). Jenis fenomenologi menurut Creswell (2014:452) menggambarkan arti sebuah pengalaman hidup beberapa orang tentang sebuah konsep atau fenomena.

Informan penelitian adalah orang yang dimanfaatkan untuk memberikan informasi tentang situasi dan kondisi latar belakang penelitian. Informan dimanfaatkan untuk berbicara, bertukar pikiran, atau membandingkan suatu kejadian yang ditemukan dari subyek lainnya (Moelong, 2005:133). Oleh karena itu, informan adalah orang-orang yang 
dijadikan sebagai sumber data yang diperlukan peneliti dalam penelitian untuk menggali informasi yang diinginkan dan dibutuhkan. Dalam penelitian ini, penentuan informan dilakukan dengan menggunakan teknik purposive sampling dengankriteria penentuan informan dalam penelitian ini yaitu. (a) Informan memiliki pengetahuan dan pengalaman yang peneliti perlukan, (b) Memiliki kemampuan komnikasi yang baik, (c) Informan memiliki waktu untuk diwawancara, (d) Informan berkemauan untuk ikut berpartisipasi terkait apa yang diteliti. Teknik pengumpulan data yang digunakan oleh peneliti dalam penelitian ini adalah observasi, wawancara, dan dokumentasi. Setelah data diperoleh, kemudian diolah dengan teknik reduksi data, penyajian data, dan penarikan kesimpulan.

\section{HASIL DAN PEMBAHASAN}

\section{Deskripsi Hasil Penelitian}

\section{A. Peran Karang Taruna Desa Maria Kecamatan Wawo Kabupaten Bima Dalam Menumbuhkembangkan Moral Generasi Muda.}

Deskripsi data hasil penelitian yang diperoleh, peran karang taruna dalam penumbuhkembangkan moral generasi muda di Desa Maria Kecematan Wawo Kabupaten Bima dapat dicermati dari substansi peran karang taruna sebagai motifator dan pembina generasi muda yang meliputi kegiatan karang tauna dalam penumbuhkembangan moral generasi muda, dalam penumbuhkembangan moral generasi muda meliputi beberapa kegiatan program kerja yang terlaksana oleh karang taruna sebagai berikut: 1) bidang kerohanian dan agama, 2) bidang olahraga, 3) bidang seni dan budaya lokal, 4) bidang kelestarian alam dan lingkungan, perencaanan program kegiatan karang taruna dan tata cara pergaulan dalam kegiatan karang taruna. yakni sebagai berikut:

1. Karang Taruna Dalam Penumbuhkembangan Moral Generasi Muda.

Generasi muda adalah generasi penerus bangsa dan pemudalah yang menjadi pemegang tongkat estafet perjuangan dan pembangunan bangsa Indonesia kedepanya guna bersaing secara global. Kondisi pemuda saaat ini mengalami degradasi moral, terlena dengan kesenangan dan lupa akan tanggung jawab sebagai seorang pemuda (Herni, 2018:5). Generasi muda dihadapkan dengan berbagai masalah dan aneka ragam pengalaman moral yang menyebabkan mereka bingung untuk memilih mana yang baik untuk mereka. Masalah yang terdapat dalam kehidupan generasi muda juga dapat menghambat perkembangan moralnya, karena perkembangan moral terjalin dalam perkembangan pribadi seseorang pemuda. Maka dari itu didirikan karang taruna dengan tujuan untuk memberikan pembinaan dan pemberdayaan kepada generasi muda, misalnya dalam bidang keorganisasian, ekonomi, sosial, keagamaan, moral dan kesenian untuk mempraktekan dan menumbuhkembangkan moralitas generasi muda. Begitupun yang terjadi di Desa Maria Kecamatan Wawo Kabupaten Bima ,terdapat beberapa kegiatan karang taruna yang dapat menumbuh kembangkan moral pemuda dengan melaksanakan pembinaan moral berupa membersihkan mesjid dan sholat berjamaah. Tujuan kegiatan ini agar generasi muda menjadi generasi yang 
bermoral bagus dan jiwa sosial yang baik. kegiatan ini dilakukan oleh pengurus karang taruna yang bekerjasama dengan pemdes dan Polsek Kecamatan Wawo.

2. Kegiatan Karang Taruna Dibeberapa Bidang.

a) Kegiatan karang taruna dalam bidang kerohanian dan agama.

Karang taruna dijadikan sebagai wadah untuk melatih diri dengan membiasakan melakukan aktifitas yang positif dan sesuai dengan agama yang dianut. Ada beberapa program kerja yang diadakan oleh karang taruna yang memasukan unsur keagamaan agar anggota tidak melupakan apa yang menjadi dasar dan menjadi pedoman seseorang untuk hidup. Program kerja karang taruna dalam bidang keagamaan antara lain: 1). Kegiatan peringatan Isra Mi'raj 2) Memperingati Maulid Nabi SAW 3). Mengadakan gotong royong untuk menjaga kebersihan lingkungan mesjid 4). Mengikutsertakan masyarakat dan generasi muda di setiap lomba yang bersifat keagamaan.

b) Kegiatan Karang Taruna Dalam Bidang Olahraga.

Melalui kegiatan dibidang keolahragaan menjadi salah satu hal yang sangat diminati oleh pemuda Desa Maria Kecamatan Wawo. Pada bidang olahraga pemuda antusias dan ikut berperan aktif pada program kerja yang diselenggarakan oleh karang taruna. Pembina karang taruna berharap melalui karang taruna ini mampu membuat pemuda menjadi genrasi yang kompeteitif dalam bidang keolahragaan dan siap untuk melanjutkan tongkat estafet dalam mangharumkan nama Desa Maria.

Program kerja yang terlaksana yang dilakukan oleh karang taruna dalam bidang olahraga sebagai berikut:

a. Pelatihan sepak bola rutin di setiap hari sabtu,

b. Pendampingan pelatihan lomba keolahragaan tingkat SD, SMP oleh Sekolah, Pemerintah Kecamatan Wawo dan pengurus karang taruna.

c. Lomba keolahragaan dalam rangka memperingati hari Kemerdekaan Indonesia.

Kemudian pada tanggal 19 Februari 2021, hasil wawancara dengan Karmilah S.Pd selaku koordinator di bidang olahraga karang taruna Desa Maria Kecamatan Wawo Kabupaten Bima, menuturkan bahwa:

Terselenggaranya kegiatan yang bergerak dalam bidang olahraga dilakukan secara sukarela oeh pemuda karang taruna Desa Maria. Dengan melihat antusias pemuda dalam rapat kegiatan di bidang keolahragaan. Segala hal yang dilakukan oleh pengurus dan anggota karang taruna bersifat sukarela.

c) Bidang Seni Dan Budaya Lokal

(Nawari Ismail, 2011) Menjelaskan tentang seni dan budaya local adalah semua ide, aktivitas dan hasil aktivitas manusia dalam suatu kelompok masyarakat di lokasi tertentu, seni dan budaya local tersebut secara actual masih tumbuh dan berkembang dalam masyarakat serta di sepakati dan dijadikan 
pedoman bersama.

Kegiatan melestarikan seni budaya lokal ini dilakukan dengan berbagai unsur masyarakat, seperti: tokoh adat, tokoh masyarakat, aparat desa dan tokoh seni. Seni budaya lokal menurut karang taruna akan terus dilestarikan sampai kapan pun, meskipun pada saat ini menghadapi tantangan yang luar bisa dari seni budaya modern. Oleh karena itu, keberadaan sanggar seni menjadi sangat penting sebagai wahana untuk memelihara seni budaya lokal. Karang taruna berkomitmen untuk memelihara seni budaya lokal. Secara berkala, karang taruna melaksanakan kegiatan festival seni budaya, seperti qasidah klasik, tarian tradisional suku Mbojo. Seni pencak silat dan adu kepala sebagai unggulan yang selalu ditampilkan sebagai tari persembahan ketika ada kunjungan pejabat pemerintah atau wisatawan. Seni pencak silat, dimainkan oleh anak-anak dan remaja, begitupun dengan adu kepala.

Kemudian karang taruna menyelenggarakan kegiatan festival seni budaya dan pencarian bakat. Pada kegiatan tersebut dilombakan seni musik tradisional, dan seni musik Islami, yang diikuti oleh kaum remaja putra maupun putri yang berada di Desa Maria Kcamatan Wawo.

d) Bidang pelestarian alam dan lingkungan

(Otto, Soemarwoto, 2019:91). Pelestarian alam dan lingkungan adalah kesesuaian manusia atas benda dan kondisi alam yang ditempati oleh manusia untuk menyeimbangkan peristiwa-peristiwa dan menghindari ancaman ketidakseimbangan yang ada di alam.

Sebagai bentuk kepedulian terhadap kelestarian lahan dan konservasi alam, karang taruna Desa Maria Kecamatan Wawo bekerjasama dengan warga Desa Maria, melakukan kegiatan penanaman pohon. Kegiatan dengan menanam 1000 bibit pohon di Daerah aliran sungai dan mata air wobo, Desa Maria Kecamatan Wawo.

Menurut ketua karang taruna Ridwan Syaidin, S.Pd, pihaknya melakukan inisiasi gerakan penanaman 1000 pohon ini sebagai wujud kepedulian pemuda yang tergabung dalam karang taruna pelopor terhadap kelestarian lingkungan. "Penanaman tanaman konservasi seperti ini merupakan program karang taruna pelopor Desa Maria. Kami juga banyak menanam di kawasan wisata alam," jelasnya. Sementara itu kepala Dusun panggalasa, Sukirman mengatakan, kegiatan penanaman tanaman konservasi kali ini merupakan lanjutan dari 150 pohon sengon yg sudah ditanam sebelumnya.

3. Perencaanan Program Kegiatan Karang Taruna

Dalam melaksanakan kegiatan hal yang utama atau pokok adalah merencanakan progam kegiatan. Sebelum merencanakan sebuah progam kegiatan pasti ada musyawarah terlebih dahulu untuk mengambil keputusan atas progam kegiatan yang akan dilaksanakan. Ada beberapa progam kegiatan yang ada di karang taruna yaitu: 


\begin{abstract}
a. Bidang kerohanian dan agama
b. Bidang pelestarian alam dan lingkungan

c. Bidang seni dan budaya lokal

d. Bidang pengembangan olahraga
\end{abstract}

Berdasarkan pengamatan dari hasil observasi saat rapat membahas kegiatan karang taruna telah menanamkan nilai moral itu sendiri terhadap generasi muda, dimana dalam berlangsungnya rapat tersebut terjadi adanya musyawarah. Musyawarah itu sendiri menurut pengurus karang taruna merupakan cara yang terbaik untuk mendapatkan sebuah keputusan terlepas ketika menuju mufakat dalam musyawarah, yang didalamnya terjadi silang pendapat, emosi yang kurang terkontrol karena mempertahankan sebuah pendapat. Hal tersebut diperkuat dengan adanya dokumentasi saat berlangsungnya rapat, sebagai berikut.

4. Tata Cara Pergaulan Dalam Kegiatan Karang Taruna.

Di dalam sebuah organisasi pasti ada tata cara pergaulan yang terdapat di dalam organisasi tersebut. Tata cara pergaulan yang dimaksud disini adalah keaktifan para anggota karang taruna Desa Maria Kecamatan Wawo, apakah saling menyapa satu sama lain dan menghargai satu sama lain dengan sesama anggotanya, dengan masyarakat sekitar dan apakah aktif dalam mengeluarkan pendapat serta menyanggah pendapat orang lain di dalam kegiatan karang taruna.

Menurut hasil pengamatan penulis selama penelitian berlangsung banyak para anggota yang selalu menyapa dan berjabat tangan ketika bertemu dengan salah satu anggota karang taruna baik di dalam forum organisasi maupun diluar kegiatan organisasi itu sendiri, walaupun ada juga beberapa anggota yang masih pasif dengan alasan malu. Hal tersebut juga diperkuat dengan hasil wawancara salah satu anggota karang taruna yang bernama $M$. yusuf yang masuk dalam devisi bidang pengabdian masyarakat dalam kepengurusan karang taruna yaitu sebagai berikut:

"Sebenarnya saya tidak pasif akan tetapi saya takut salah dan malu apabila mengutarakan pendapat di depan umum" (wawancara pada tanggal 12 Januari 2021).

\title{
B. Faktor Pendukung Dan Penghambat Kegiatan Karang Taruna Desa Maria Kecamatan Wawo Kabupaten Bima Dalam Menumbuh Kembangkan Moral Generasi Muda.
}

1. Faktor pendukung

Adapun faktor pendukung dalam penumbuhkembangan moral generasi muda di Desa Maria Kecamatan Wawo Kabupaten Bima adalah tersedianya prasarana ibadah dan adanya pengajian rutin pemuda, Faktor pendorong lainnya adalah bertitik tolak dari lingkungan yang harmonis, sehingga lingkungan keluarga dalam hal ini sangat berperan penting, dalam keluarga seorang anak akan mendapati hal-hal yang tidak didapati di lingkungan formal maupun lingkungan masyarakat, seperti perhatian, kasih sayang dan lain sebagainya. Sehingga lingkungan keluarga dalam penumbuhkembangan moral generasi muda perlu memperhatikan kebutuhan 
pemuda, serta mengarahkan apa yang ia lakukan agar generasi muda dapat mengetahui mana yang baik dan buruk. Keluarga menjadi panutan dan contoh untuk kepribadiannya, tingkah laku orang tua selalu menjadi tolak ukur anak dalam proses pendidikan dalam keluarga, anak akan meniru orang tua dalam bersikap dan berprilaku.

a. Sarana dan prasarana

Sarana dan prasarana karang taruna merupakan pendukung utama dalam berlangsungnya suatu kegiatan. Sarana dan prasarana tersebut meliputi tempat Karang Taruna untuk mengadakan rapat atau menyimpan dokumen-dokumen penting yang berhubungan dengan karang taruna, teknologi yang selalu mengikuti perkembangan dan lain sebagainya yang mendukung terlaksananya suatu kegiatan.

Berdasarkan pengamatan penulis di karang taruna Desa Maria Kecamatan Wawo Kabupaten Bima, sarana dan prasarana telah mendukung terlaksananya suatu progam kegiatan. Terlebih lagi fasilitas yang diberikan oleh pihak kelurahan kepada karang taruna. Sarana dan prasarana tersebut antara lain aula balai Desa Maria yang bisa dipakai kapan saja untuk menunjang kegiatan karang taruna, serta sebuah ruko dari kepala Desa yang diberikan kepada karang taruna yang dapat digunakan sebagai tempat pengembangan wirausaha oleh-oleh desa sebagai rintisan desa pariwisata. Hal ini juga diperkuat dengan hasil dokumentasi saat pelaksanaan kegiatan berlangsung, yaitu sebagai berikut.

b. Dukungan dari pihak Desa dan Masyarakat

Berhasilnya suatu kegiatan karang taruna tidak terlepas dari dukungan dari pihak kelurahan. kegiatan karang taruna mendapat dukungan yang sangat baik dari pihak kelurahan itu sendiri, dan mendukung semua kegiatan karang taruna Desa Maria Kecamatan Wawo Kabupaten Bima selama kegiatan tersebut dapat membawa dampak positif bagi pemuda Desa Maria yang mengikuti kegiatan karang taruna Desa Maria Kecamatan Wawo Kabupaten Bima.

2. Faktor Penghambat.

Suatu organisasi dalam melaksanakan program-programnya untuk mencapai tujuan yang diharapkan tidaklah selalu berjalan dengan lancar, akan tetapi tidak terlepas dari kendala-kendala atau hambatan-hambatan, begitu juga dengan organisasi karang taruna.

Hambatan-hambatan yang ditemui dalam pelaksanaan aktifitasaktifitas karang taruna sebagaimana yang dikatakan oleh Sahrul Fath "Hambatan-hambatan yang ditemui dalam pelaksanaan program kerja karang taruna diantaranya adalah: masalah dana (anggaran), keaktifan pemuda dalam mengikuti kegiatan, dan tenaga pembina.

a. Masalah Dana (anggaran),

Dana (anggaran) merupakan faktor penting dan ikut menentukan berhasil atau tidaknya kegiatan yang dilaksanakan oleh suatu organisasi. Oleh sebab itu dana (anggaran) harus betul-betul diperhatikan untuk menunjang kelancaran 
pelaksanaan program kerja suatu organisasi. Dana dipergunakan untuk keperluan karang taruna sebagaimana yang dijelaskan oleh Intan “ Dana diperoleh berasal dari sumbangan ketua-ketua kampung dan bantuan dari Pemerintah Desa, jumlah dana tersebut juga masih jauh dari keperluan untuk kegiatan karang taruna.

Dengan demikian dana merupakan masalah yang sangat penting dalam menunjang pelaksanaan aktifitas pemuda karang taruna tanpa didukung oleh dana yang memadai semua program kegiatan akan mengalami hambatanhambatan.

b. Kurang aktifnya generasi muda karang taruna dalam mengikuti kegiatan.

Kurang aktifnya generasi muda karang taruna dalam mengikuti aktifitas-aktifitas juga merupakan kendala bagi pelaksanaan program kerja, sebab dengan adanya anggota yang kurang aktif dalam mengikuti aktifitas dapat mempengaruhi anggota yang lain untuk ikut tidak aktif. Begitu juga dengan anggota-anggota yang kurang aktif dapat menyebabkan suatu kegiatan tidak berjalan dengan baik. Misalnya : pada kegiatan olah raga, jika pemainnya kurang tentu saja kegiatan tersebut tidak berjalan lancar, begitu juga dengan kegiatan-kegiatan lainnya.

c. Kurang Tenaga Pembina.

Faktor tenaga pembina merupakan salah satu bagian yang sangat menentukan untuk keberhasilan pembinaan. Oleh sebab itu tenaga pembina perlu mendapat perhatian terutama dari segi keilmuan, kecakapan dan kesanggupan menjalankan tugas sebagai pembina. Tenaga pembina yang dimaksud misalnya : Pembimbing pengajian, kesenian, penceramah. Masalah kesulitan tenaga pembina ini seperti yang dijelaskan oleh Syahrul Fath adalah : tenaga pembina karang taruna sangat terbatas. Hal ini berhubungan dengan masih rendahnya sebagian pendidikan remaja, sehingga menyebabkan ketergantungan kepada beberapa orang pembina saja.Misalnya : kegiatan pengajian remaja, jika tenaga pembina tidak hadir maka kegiatan tersebut tidak dilaksanakan karena tidak ada yang menggantikannya, disamping itu dengan rendahnya pendidikan remaja juga menyebabkan sulitnya pengkaderan tenaga pembina. Faktor yang dikemukakan diatas merupakan bagian yang saling menunjang. Kesemuannya harus berjalan seirama, jika salah satunya tidak berjalan dengan baik maka yang lain akan demikian pula.

\section{PENUTUP}

\section{A. KESIMPULAN}

Berdasarkan data hasil penelitian dan pembahasan di atas terdapat beberapa hal yang dapat disimpulkan, sebagai berikut :

1. Peran karang taruna Desa Maria Kecamatan Wawo Kabupaten Bima dalam penumbuhkembangan moral generasi muda yaitu sebagai wadah untuk menampung 
aspirasi generasi muda dan penumbuhkembangan nilai moral serta sikap kepemimpinan dengan cara menumbuhkan rasa tanggung jawab kepada anggota karang taruna dan generasi muda melalui program kerja karang taruna yang terlaksana antara lain: (1) bidang kerohanian dan agama (2) bidang pelstarian alam dan lingkungan (3) bidang pengembangan olahraga (4) bidang seni dan budaya lokal.

2. Faktor-faktor yang mempengaruhi kegiatan karang taruna Desa Maria Kecamatan Wawo Kabupaten Bima dalam penumbuhkembangan moral generasi muda dikelompokan menjadi dua yakni faktor internal pendukung dan penghambat dan faktor eksternal pendukung. Faktor internal pendukung yaitu berupa Sarana dan prasarana yang meliputi tempat karang taruna untuk mengadakan rapat atau menyimpan dokumen-dokumen penting yang berhubungan dengan karang taruna, teknologi yang selalu mengikuti perkembangan dan lain sebagainya yang mendukung terlaksananya suatu kegiatan. Kemudian dukungan dari pihak kelurahan dan masyarakat, berhasilnya suatu kegiatan karang taruna tidak terlepas dari dukungan dari pihak kelurahan dan bantuan dari masyarakat setempat.

3. Sedangkan faktor penghambatnya berupa Dana (anggaran), yang merupakan faktor penting dan ikut menentukan berhasil atau tidaknya kegiatan yang dilaksanakan oleh suatu organisasi. Kurang aktifnya generasi muda karang taruna dalam mengikuti aktifitas-aktifitas juga merupakan kendala bagi pelaksanaan program kerja, sebab dengan adanya anggota yang kurang aktif dalam mengikuti aktifitas dapat mempengaruhi anggota yang lain. Kurangnya tenaga pembina, tenaga pembina merupakan salah satu bagian yang sangat menentukan untuk keberhasilan suatu program kerja.

\section{B. SARAN}

\section{Bagi generasi muda}

Lebih aktif dan lebih ditingkatkan lagi berpartisipasi dalam melaksanakan program kerja karang taruna dengan cara menumbuhkan rasa tanggung jawab kepada anggota karang taruna.

2. Bagi karang taruna

a. Tetap terus memberikan inovasi berupa kegiatan yang menarik minat pemuda dan remaja sehingga tujuan mengembangkan masyarakat berhasil dengan baik.

b. Bagi karang taruna hendaknya memikirkan sumber daya anggota kelompok karang taruna dan generasi muda yang semakin berkurang, pembenahan struktur kelompok, kesadaran diri dalam berorganisasi dan bersosial, perilaku kelompok serta interaksi kelompok agar peran serta karang taruna dalam penumbuh kembangan moral generasi muda dapat diterapkan sesuai dengan keinginan melalui partisipasi anggota pada setiap kegiatan yang diadakan oleh karang taruna Desa Maria Kecamatan Wawo Kabupaten Bima.

c. Bagi peneliti selanjutnya

Bagi peneliti selanjutnya yang akan melakukan penelitian dibidang ini,diharapkan penelitian ini dapat menjadi gambaran,informasi dan masukan tentang peran 
karang taruna dalam menumbuhkembankan moral generasi muda.

\section{DAFTAR PUSTAKA}

Abu, A, dan Munawar Sholeh, A. 1992. Psikologi Perkembangan. Jakarta: Rineka Cipta, Cet.1,h.92.

Arikunto, Suharsimi. 2014. Prosedur Penelitian, (Suatu Pendekatan Praktik).Jakarta: RinekaCipta

Asmaran, A. 1992. Pengantar Studi Akhlak,cet,1. (Jakarta: Rajawali Pers,),h.8.

Balai Pustaka,h.45. Zakiah Daradjat,Ilmu Jiwa Agama,h.106-107.

Creswell. 1998. Qualitative Inquiry: Choosing Among Five Traditions. USA: Sage Publications Inc

Daradjat, Zaskia.1976. Membina Nilai-Nilai Moral di Indonesia, (Jakarta: Bulan Bintang), h.8.

Depdikbud. 1991. Kamus Besar Bahasa Indonesia (Jakarta : Balai Pustaka),h.654. Dini, D. S. 2016. "Peranan Karang Taruna Dalam Meningkatkan Kepedulian Sosial Pemuda", (Skripsi), Bandar lampung:studi pendidikan pancasila dan kewarganegaraan, universitas lampung,h.18-19.

Direktorat Bina Karang Taruna. 2005. Pedoman Pembinaan Program dan Kegiatan Karang Taruna. Jakarta : Dirjen Rehabilitasi dan Pelayanan Sosial.

Echlos, J. M. 2000. Kamus Bahasa Inggris, Jakarta : Balai Pustaka, Hal.7.

Faezal, Sanapiah. 2005. Format Penelitian Sosial. Jakarta: Raja Grafindo Persada.

Fahmi, Tokoh Masyarakat Desa Maria, Dilakukan Pada Jumat, 10 April. 2020. Pukul 13.00 Wita.

Frans, M. S. 1987. Etika Dasar : masalah-masalah pokok filsafat moral (Yogyakarta: Kanisius).h.14.

Lorza, Wanti. 2019. Peran Karang Taruna Dalam Membentuk Moral Remaja Di Kecamatan Rajabasa Bandar Lampung." (Skripsi). Ushuluddin dan Studi Agama. Universitas Islam Negeri Bandar Lampung: Lampung.

Ibrahim, I. Pemerintah Desa Maria, Dilakukan Pada Senin, 13 April. 2020. Pukul 09.20 Wita.

Kurniasari, D.2013. Peran Organisasi Karang Taruna Dalam Mengembangkan Kreativitas Generasi Muda Di Desa Ngembalrejo. Unnes Civic Education Journal.H.12.

Mannan, A. 2017. Pembinaan Moral Dalam Membentuk Karakter Remaja. Jurnal Aqidah, III (1), 10-15.

Muchson, A.R. dan Samsuri. 2015. Dasar-Dasar Pendidikan Moral, Yogyakarta: Penerbit Ombak.h.45.

Mulyana, Deddy. 2001. Metodologi Penelitian Kualitatif, Paradigma Baru Ilmu Komunikasi dan Ilmu Sosial Lainnya. Bandung: Remaja Rosdakarya.

Moelong, Lexy J. 2005. Metodologi Penelitian Kualitatif (edisi revisi). Bandung: PT. Remaja Rosda Karya.

Muhammad Al-Mighwar. 2006. Psikologi Remaja (Bandung: Pustaka Setia),h.63.

Mulyawan, Wawan. 2009. Pedoman Dasar Karang Taruna. Jakarta: Departemen Sosial Republik Indonesia.

Moeslichateon, 2004. Metode Pengajaran di Taman Kanak - kanak, Jakarta: Rineka Cipta. h. $177-180$.

Nurdin. 2016. "Penerapan Remaja Dalam Pembinaan Moral, (Skripsi). Di salaludin dan 


\section{Jurnal Pendidikan Sosial Keberagaman}

Print-ISSN 2355-4622 Online-ISSN 2622-9021

Vol. 8, No. 1, Agustus 2021, halaman 54-65

https://juridiksiam.unram.ac.id/index.php/juridiksiam

studi Agama. UIN RIL. Bandar lampung.

RM, Hening, Hutomo, P. 2016.”Peran Karang Taruna Sangguh Jaya Dalam Membentuk Sikap Kepemimpinan Pemuda di Kawasan Desa Wisata Brontokusuman”, (Skripsi, Yogyakarta: Studi Pendidikan Luar Sekolah, Yogyakarta),h.15.

Ramlin Ketua Karang Taruna Desa Maria. Wawancara Di Lakukan Pada. Jum'at, 10 April 2020. 09.00Wita.

Riyadi, 2002. Perencanaan Pembangunan Daerah Strategi Mengendalikan Potensi Dalam Otonomi Daerah, (Jakarta. Gramedia),h.138.

Slavin, Robert E. (2008). Psikologi Pendidikan: Teori dan Praktik. Jakarta: PT. Indeks.

Sarlito, W. S. 2008. Psikologi Remaja (Jakarta: RajaGrafindo Persada),h.14.

Sugiyono, 2018. Metode Penelitian (Kuantitatif, Kualitatif, dan $R \& D$ ). Alfabeta:Bandung.

Sutarjo, Adisusilo, J.R. 2013. Pembelajaran Nilai Karakter, Konstruktivisme dan VCT Sebagai Inovasi Pendekatan Pembelajaran Afektifitas, (Jakarta:Rajawali Pers, Cet.2),h.4.

Susanti, Herni. 2018. Generasi Muda Penerus Bangsa. Buleleng: Herni.

Wila, Huky. 2003. Dasar-Dasar Pengertian Moral (Jakarta).

Yusransyah ,M. 2014. Pengembangan Moral Dan Nilai-nilai Agama Anak Usia Dini, ( http ://kundari paud. Wrodpress. Com, di akses pada tanggal 16 Desember 2016.

Zakiah, Daradjat. 1970. Ilmu Jiwa Agama(Jakarta: Bulan Bintang), h.156.

Zakiah, Daradjat. 1976. Membina Moral-Moral di Indonesia, (Jakarta: Bulan Bintang), Cet Ke-3, h.13.

Zaky, 18 Februwari. 2020. https://www.zonareferensi.com/pengertian-moral/, Di akses tanggal 20 Oktober. 2020.

https://www.hukumonline.com/klinik/detail/ulasan/lt52ef26d6b1e2e/dasar-hukum-karangtaruna/, Di akses tanggal 10 Oktober. 2020. 